\title{
PATTERN OF SPINAL TUBERCULOSIS AT LIAQUAT UNIVERSITY HOSPITAL, HYDERABAD/JAMSHORO
}

\author{
Bikha Ram Devrajani, Rafi Ahmed Ghori, Nizamuddin Memon and Muhammad Ali Memon
}

\begin{abstract}
OBJECTIVE: To find out the pattern of spinal tuberculosis (TB) presenting as paraplegia/ paraparesis in our set up.

DESIGN: A descriptive study.

SETTING: Department of Medicine, Liaquat University Hospital Jamshoro/Hyderabad - Sindh from July 2003 to August 2004.

METHODS: In this study, 44 patients having TB spine presenting as paraplegia/paraparesis were evaluated by haematology, sputum examination, urine analysis, biochemistry and imaging. These patients also underwent a detailed history and clinical examination. Patients having non-tubercular cases of paraplegia and children were excluded from the study.

RESULTS: Age range of the patients was 18-62 years. Among study participants, there was male dominance $(61.36 \%)$ as compared to females (38.64\%). Pott's disease was present in 26 (59.09\%) cases, paravertebral abscess with vertebral body destruction in $2(4.54 \%)$ cases, without body destruction in $4(9.09 \%)$ cases and spinal stenosis in 2(4.54\%) cases. Arachnoiditis was seen in $10(22.73 \%)$ cases while spinal ischaemia in $2(4.54 \%)$ cases. In region-wise distribution, thoracic was involved in 20(45.45\%)cases, lumbar 12(27.27\%) cases, diffuse 10 cases (22.73\%) and cervical $2(4.54 \%)$ cases. Thirty $(68.18 \%)$ cases improved neurologically after medical and surgical treatment while $14(31.82 \%)$ cases did not improve because of delay in the diagnosis and treatment.

CONCLUSION: In our set up, TB spine is more common in males than females and mostly presents with history of fever and backache resulting into paraplegia and paraparesis. Thoracic region is more common area of involvement. Most common pattern of TB spine is Pott's disease. Recovery among these patients is remarkable if diagnosed earlier.
\end{abstract}

KEY WORDS: Tuberculosis. Spine. Pott's disease. Arachnoiditis. Management.

\section{INTRODUCTION}

Tuberculosis (TB) is a major infectious disease of developing countries including Pakistan, in the etiology of paraplegia. It can cause paraplegia by infecting the vertebrae and compressing the spinal cord and cauda equina, adhesions of meninges, arteritis of spinal vessels and multiple infarctions of spinal cord. It can also lead to the tuberculoma of brain and the spinal cord. Tuberculosis of spines may destroy a number of vertebrae. Pereival Pott described the disease in 1799 and it was named after him. ${ }^{1}$ Infection of vertebrae is the leading cause of non-traumatic paraplegia in developing countries and tuberculosis is still main infectious disease of vertebrae next to lung involvement. TB spine may lead to either early onset paraplegia or late onset paraplegia. Early onset paraplegia occurs during active stage of vertebral TB because of inflammatory oedema, granulation tissue, abscess, caseous tissue and rarely ischaemic lesion of the cord. Late onset paraplegia can develop even many years after the disease has persisted in vertebrae. Paraplegia may be due to recurrence of the disease or caused by mechanical pressure. TB mostly involves the anterior segment (body) and inter-vertebral disc of spines and there can be Kyphosis and Gibbus formation due to vertebral body collapse and stenosis of the vertebral canal leading to paraplegia, secondary to cord compression. ${ }^{2}$ But, other parts of vertebrae may also be affected by TB e.g. posterior segment of vertebrae. ${ }^{3}$ However, one must be careful to look into neurological signs in patients, in those who are already on anti-tuberculosis treatment, without manifesting neurological symptoms because these patients may develop paraplegia even after many years. TB may also lead to paravertebral cold abscesses and paraplegia secondary to spinal cord compression. ${ }^{4}$ Paraplegia due to epidural mass (a healing response TB granuloma) has also been reported. ${ }^{5}$ Pott's paraplegia is usually slow onset. It first presents as spontaneous twitching of the muscles in the lower limbs, extensor plantar response and exaggerated reflexes of lower limbs. Motor functions 
are affected before sensory functions. Then, paralysis usually passes through spastic motor paralysis, spastic paraplegia in extension and later on spastic paraplegia in flexion. In very advance cases, bladder and anal sphincters may be involved. There may be varying degree of sensory deficits. Sometimes, Pott's paraplegia may be sudden in onset due to thromboembolism or transection of spinal cord because of pathological dislocation. ${ }^{6,7}$ Cerebrospinal fluid (CSF) analysis is the basic investigation of undiagnosed central nervous system illnesses but if there is highly raised CSF pressure and subarachnoid block, then, with lumbar puncture, condition of patient may detoriate due to conning. In these conditions, routine lumbar puncture can be postponed or performed under neurological supervision. ${ }^{8}$ CSF analysis can guide to find out the spinal tuberculosis. Paraplegia due to tuberculosis meningitis have CSF with raised proteins, reduced sugar and lymphocytes. ${ }^{9}$ Serial plain radiography can be used for assessing the healing of infectious vertebral diseases. Among these cases, serial radiography has been proved to be good tool to assess the progress of disease. ${ }^{10-11} \mathrm{MRI}$ is good detector of activity of TB spondylitis ${ }^{12}$ and ultrasound of abdomen in the cases of paravertebral abscess. ${ }^{13}$ This paper presents pattern of spinal tuberculosis presenting as paraplegia/paraparesis in our set up.

\section{PATIENTS AND METHODS}

This study was carried out at four medical units of Liaquat University Hospital, Jamshoro/Hyderabad from July 2003 to August 2004. This study included 44 cases of TB spine. All cases were admitted as indoor patients in four medical units and one neurosurgery unit of this hospital. Criteria for selection of patients were: paraplegia without history of trauma and adult patients. No any child was included in this study. All other cases of paraplegia were also excluded except TB spine. A detailed history of every case was taken and information was noted on a proforma, specially made for study purpose. Information was collected regarding name, age, sex, occupation, address, date of admission and date of discharge of the patients. Detailed inquiry was carried out regarding mode of onset of lower limbs weakness, history of ascending paralysis, fever, headache, backache, incontinence or retention of urine, incontinence of faeces, constipation, joint pains, unconsciousness and duration of all above mentioned symptoms. In the past history, information about pulmonary tuberculosis, syphillis, leprosy, fits, chronic pharyngitis, meningitis and any tumour was collected. Regarding personal and family history, attention was paid to alcoholism, diabetes mellitus, ischaemic heart disease and family or hereditary ataxias. Clinically, all patients were examined for anaemia, oedema, lymphadenopathy, skin changes, joints, vertebral column tender spots and Gibbus formations. Detailed clinical examination of central nervous system was performed in all patients. Respiratory, cardiovascular system and abdomen were also examined in each case. Blood of all patients was investigated for complete blood picture, sugar, urea and electrolytes. Lumbar puncture of all patients was done after antiseptic measures. Xray chest (PA view) was advised for all cases to see the evidence of pulmonary tuberculosis, primary and secondary tumour, cysts, pleural effusion, lung abscess, lung infarction, aortic abnormalities, cardiac size abnormalities and any abnormality of the chest wall. Plain X-ray for vertebral column was also done in all cases for any evidence of body destruction, kyphosis, osteoporosis, collapse of vertebrae, osteolytic and osteoblastic lesions, spurs, bamboo spine, prolapse of intervertebral discs, paravertebral shadows, psoas abscess and congenital bony abnormalities. Procedures of myelography and radiculography were performed under fluoroscopy after injecting a contrast medium (i.e. Iopomidol 10 $\mathrm{CC}$ ) in spinal subarachnoid space by performing lumbar puncture in between L4/L5 in 42(95.45\%) cases. CT scanning was advised in $17(38.64 \%)$ cases while MRI was performed in four cases. Sputum for detailed report, acid-fast bacilli (AFB) and cytology was sent in 26 cases. Bone scanning by perfusion was advised in two cases from Radio-Isotope Centre, Jamshoro.

\section{RESULTS}

Age range of the patients was $18-62$ years. Majority of the patients belonged to District Hyderabad of Sindh province (Table I). Clinically, fever was present in 40 (90.91\%) patients, backache in $36(81.82 \%)$, headache in $8(18.18 \%)$, urinary retention in 32 $(72.73 \%)$ and faecal incontinence in $12(27.27 \%)$ cases. Four (9.09\%) patients were unconscious at the time of admission. In the past history, 10(22.73\%) patients were having pulmonary tuberculosis and 6 (13.64\%) had TB meningitis (Tables II and III). On general physical examination, anaemia was present in 26(59.09\%) cases, vertebral tender spot in 18 (40.91\%) and typical Gibbus formation in 12(27.27\%) cases. Clinical examination of motor system revealed upper motor neuron lesion in $16(36.36 \%)$ cases and lower motor neuron lesion in $28(63.64 \%)$ cases. Posterior column was involved in 26(59.09\%) cases and lateral column in $12(27.27 \%)$ cases. Signs of meningeal irritation were noted in $6(13.64 \%)$ cases 
Bikha Ram Devrajani, Rafi Ahmed Ghori, Nizamuddin Memon, et al

only. On clinical examination of chest, 4 cases had signs of pulmonary tuberculosis. Cardiovascular system was normal in all cases. On abdominal examination, only distended urinary bladder was found in 16 cases. Blood was sent for complete picture in each case. Haemoglobin level ranged from $8.2 \mathrm{~g} / \mathrm{dL}$ to $11.8 \mathrm{~g} / \mathrm{dL}$. ESR was less than $10 \mathrm{~mm}$ in first hour reading in $8(18.18 \%)$ cases, more than 10 and less than 50 in 20(45.45\%) cases, and more than 50 $\mathrm{mm}$ in $16(36.36 \%)$ cases. CSF examination revealed typical signs of TB (i.e. rise in proteins, reduced sugar, lymphocytes and coagulum positive) in 10 (22.73\%) cases. In $14(31.82 \%)$ cases, proteins were highly increased with xanthomatous appearance and in 10 (22.73\%) cases, CSF examination showed only marginally raised proteins. Urine $D / R$ showed pus cells more than 20 in 32 cases. Urine sugar was positive in 6 cases (these patients were known diabetics). All other parameters were normal in urine examination. Plain radiography of spines (anteroposterior and lateral views) showed decreased intervertebral spaces in 8(18.18\%) cases, collapsed vertebral bodies in 6(13.64\%), osteoporotic changes in vertebral bodies in single case, typical kyphoscoliosis in 6(13.64\%) cases and typical paravertebral abscesses in 6(13.64\%) cases. Among these cases, one patient had collapsed vertebral bodies with paravertebral abscess and other 4 cases had only paravertebral abscess without collapsed vertebral bodies. Eight patients had normal X-rays of spines. Chest radiography revealed evidence of old healed pulmonary TB in 4(9.09\%) cases, hilar calcifications in 4(9.09\%), active pulmonary TB in 6 (13.64) cases and miliary TB in one case. Twentyeight patients were having normal chest X-rays. Myelography was performed in 42 patients out of 44 cases of spinal TB. Complete spinal block was noted in $28(63.64 \%)$ patients. In 12 cases, there were lower dorsal blocks, in 6 patients at the level of upper lumbar vertebrae, 4 cases each in upper thoracic and lower lumbar vertebrae while cervical block was noted in only one case. Myelogram in one case was typical of spinal stenosis and in $10(22.73 \%)$ cases of arachnoiditis. Two patients of TB spine had normal myelogram. CT scanning of spines was advised for those 17 patients in which X-rays of spines were normal. It was normal in 6 cases, one patient proved to be a case of spinal stenosis and in 8 cases, there were destructive changes in vertebral bodies. Tissue biopsy was taken in 26(59.09\%) cases. In 22 cases, it was taken during surgical procedure and from 4 cases by needle aspiration of paravertebral abscess. All these cases proved of TB. In $26(59.09 \%)$ cases, there were lesions in vertebral bodies and causing the compression of spinal cord, in one case paravertebral abscess with destruction of bodies of 4 vertebrae, in 4 cases paravertebral abscess without bony destruction and pussy material was compressing the spinal cord and in one case TB was causing the spinal stenosis leading to the spinal cord compression (Table IV). Arachnoiditis was noted in 10 cases. One case had normal spinal radiography, normal myelography with typical CSF findings of TB and possible pathogenesis was spinal cord ischaemia. Region-wise distribution of the cases is presented in Table $\mathbf{V}$. All 44 cases of TB spine were treated with anti-Koch's treatment (all four drugs i.e. Rifampcin, Pyrazinamide, Isoniazid and Ethambutol). Eleven patients undergone laminectomy (decompression of spinal cord). Sixteen cases had complete recovery within 6 months, 8 cases improved with grade-III power in lower limbs and 6 cases up to grade-II power. Fourteen cases out of total 44 cases did not respond to management even after 6 months follow-up (these cases arrived in hospital with legs weakness for more than 8 months and less than 2 years). Total duration of treatment was 18 months.

TABLE I:

\section{DISTRICT WISE DISTRIBUTION OF CASES OF SPINAL TUBERCULOSIS ( $n=44)$}

\begin{tabular}{|l|c|c|c|c|}
\hline \multirow{2}{*}{ District } & \multicolumn{3}{|c|}{ Number of Patients } & \multirow{2}{*}{$\begin{array}{c}\text { Percent- } \\
\text { age }\end{array}$} \\
\cline { 2 - 4 } & Male & Female & Total & \\
\hline Hyderabad & 10 & 8 & 18 & $40.91 \%$ \\
\hline Dadu & 5 & 2 & 7 & $15.91 \%$ \\
\hline Thatta & 3 & 2 & 5 & $11.36 \%$ \\
\hline $\begin{array}{l}\text { Naushehro } \\
\text { Feroze }\end{array}$ & 3 & 1 & 4 & $9.09 \%$ \\
\hline Mirpurkhas & 3 & 0 & 3 & $6.82 \%$ \\
\hline Thar & 0 & 2 & 2 & $4.54 \%$ \\
\hline Badin & 1 & 1 & 2 & $4.54 \%$ \\
\hline Larkana & 1 & 1 & 2 & $4.54 \%$ \\
\hline Nawabshah & 1 & 0 & 1 & $2.27 \%$ \\
\hline Total & 27 & 17 & 44 & $99.98 \%$ \\
\hline
\end{tabular}


TABLE II:

DURATION OF SYMPTOMS OF CASES OF TUBERCULOSIS OF SPINE $(n=44)$

\begin{tabular}{|l|c|c|c|}
\hline \multicolumn{1}{|c|}{ Symptom } & $\begin{array}{c}\text { Mean } \\
\text { duration }\end{array}$ & $\begin{array}{c}\text { Number } \\
\text { of cases }\end{array}$ & $\begin{array}{c}\text { Percent- } \\
\text { age }\end{array}$ \\
\hline Fever & 3 months & 40 & $90.91 \%$ \\
\hline Backache & 2 months & 36 & $81.82 \%$ \\
\hline $\begin{array}{l}\text { Urinary retention/ } \\
\text { incontinence }\end{array}$ & 3 weeks & 22 & $50.00 \%$ \\
\hline $\begin{array}{l}\text { Faecal } \\
\text { incontinence }\end{array}$ & 2 weeks & 12 & $27.27 \%$ \\
\hline
\end{tabular}

TABLE III:

CLINICAL FEATURES OF CASES OF

TUBERCULOSIS OF SPINE $(n=44)$

\begin{tabular}{|c|c|c|}
\hline Symptom/Sign & $\begin{array}{l}\text { Number } \\
\text { of cases }\end{array}$ & $\begin{array}{l}\text { Percent- } \\
\text { age }\end{array}$ \\
\hline \multicolumn{3}{|l|}{ Past History } \\
\hline Pulmonary TB & 10 & $22.73 \%$ \\
\hline TB Meningitis & 06 & $13.64 \%$ \\
\hline Diabetes Mellitus & 04 & $09.09 \%$ \\
\hline \multicolumn{3}{|l|}{ Signs } \\
\hline $\begin{array}{l}\text { Lower motor neuron } \\
\text { lesion }\end{array}$ & 28 & $63.64 \%$ \\
\hline Anaemia & 26 & $59.09 \%$ \\
\hline $\begin{array}{l}\text { Posterior column } \\
\text { impairment }\end{array}$ & 26 & $59.09 \%$ \\
\hline Vertebral tender spot & 18 & $40.91 \%$ \\
\hline $\begin{array}{l}\text { Upper motor neuron } \\
\text { lesion }\end{array}$ & 16 & $36.36 \%$ \\
\hline $\begin{array}{l}\text { Typical Gibbus } \\
\text { formation }\end{array}$ & 12 & $27.27 \%$ \\
\hline $\begin{array}{l}\text { Lateral column } \\
\text { impairment }\end{array}$ & 12 & $27.27 \%$ \\
\hline $\begin{array}{l}\text { Signs of meningeal } \\
\text { irritation (neck rigidity/ } \\
\text { Kernig's sign) }\end{array}$ & 06 & $13.64 \%$ \\
\hline
\end{tabular}

TABLE IV:

PATTERN OF PARAPLEGIA I PARAPARESIS DUE TO TUBERCULOSIS

\begin{tabular}{|l|c|c|}
\hline \multicolumn{1}{|c|}{ Pattern } & $\begin{array}{c}\text { Number of } \\
\text { cases }\end{array}$ & $\begin{array}{c}\text { Percent- } \\
\text { age }\end{array}$ \\
\hline Pott's disease & 26 & 59.09 \\
\hline $\begin{array}{l}\text { Paravertebral abscess } \\
\text { with vertebral bony } \\
\text { destruction }\end{array}$ & 02 & 04.54 \\
\hline $\begin{array}{l}\text { Paravertebral abscess } \\
\text { without vertebral bony } \\
\text { destruction }\end{array}$ & 04 & 09.09 \\
\hline Spinal stenosis & 02 & 04.54 \\
\hline Arachnoiditis & 10 & 22.73 \\
\hline Spinal cord ischaemia & 02 & 04.54 \\
\hline
\end{tabular}

TABLE V:

REGION WISE DISTRIBUTION OF TB SPINE CASES $(n=44)$

\begin{tabular}{|l|c|c|}
\hline \multicolumn{1}{|c|}{ Region } & $\begin{array}{c}\text { Number of } \\
\text { cases }\end{array}$ & Percentage \\
\hline Cervical & 02 & 4.54 \\
\hline Thoracic & 20 & 45.45 \\
\hline Lumber & 12 & 27.27 \\
\hline $\begin{array}{l}\text { Diffuse involvement } \\
\text { (arachnoiditis) }\end{array}$ & 10 & 22.73 \\
\hline
\end{tabular}

\section{DISCUSSION}

Tuberculosis of spine is an old age disease, also, shown in the Egyptian Mummies. It has been a common orthopaedic, neurological problem until the middle of last century for developing world. ${ }^{14}$ Resurgence of tuberculosis with HIV infection has also resulted in increased number of cases with Pott's disease in the developed world. ${ }^{15}$ In recent years, incidence of bone and joint tuberculosis in England has been about $6 \%$ of all new cases of extrapulmonary tuberculosis notified. ${ }^{16}$ Spinal tuberculosis is a common disease in our country, because of high prevalence of pulmonary tuberculosis. Forty-four cases with spinal tuberculosis, admitted with paraplegia is a mere reflection of the above 
observations. Young male preponderance and clinical pattern of onset as shown in this study is in accordance with observations made by Jalleh, et al. ${ }^{11}$ Upper motor neuron lesion in $36.36 \%$ and lower motor neuron lesion in $63.64 \%$ in this study is also in accordance with the findings of Loembe, et al. ${ }^{17}$ Fourteen cases reported with early onset paraplegia and $30(68.18 \%)$ cases presented with gradual onset, parallel with late reporting and severe cord compression. Regional distribution of vertebral column in this study is comparatively different from the findings of Boxer, et $\mathrm{al}^{10}$ where as Tulsi, et $\mathrm{al}^{18}$ have reported thoracic, cervical and lumbar involvement in order of frequency. Diagnostic value of standard radiography; CT scan and MRI have been widely discussed in the literature. ${ }^{19}$ The ideal imaging technique should give the clinician following information: 1) The number of vertebrae involved. 2) The severity of bone disease. 3) The site of involvement within the vertebrae, confined to anterior or posterior elements or both. 4) The angle of kyphosis. 5) The size of vertebral canal. 6) The soft tissue involvement including presence of para-spinal abscess and disc sequestration. 7) Extent of compression of cord or cauda equina. Cord compression may be due to extrinsic causes, which, in active disease includes fluid or caseous or granulation tissue. It could be due to sequestrated bone or disc, or in the healed disease, a transverse ridge of bone, kyphosis and fibrosis of dura or plaques on arachnoid membrane. Plain radiography does not indicate crosssectional shape of the canal, nor does it demonstrate the degree of soft tissue thickening around the articular facets and in the ligaments, which together with bulgding annulus may cause severe root compression. Myelography provides essential information in the size of remaining subarachnoid space. Vidyasagar, et $\mathrm{al}^{20}$ measured anterior-posterior diameter of contrast material and postulated that anything less than $15 \mathrm{~mm}$ was suggestive of narrow canal. Comparative evaluation of plain radiography and myelography has been discussed in detail by alArabi KM, et al. ${ }^{21}$ In this study, 28/44 cases showed various changes on plain radiography, however, 16 cases could have been missed completely, if relied on this modality alone. The extent of block (complete or partial), spinal stenosis, arachnoiditis and early bone destruction were assessed by CT scan, MRI and the myelography. It enabled us to decide for surgical procedures or to opt for conservative chemotherapy. The importance of these modalities have further been discussed by Hogson, et $\mathrm{al}^{22}$, Hoffman, et $\mathrm{al}^{19}$ and Kutty $\mathrm{S}^{23}$. Five $(11.36 \%)$ cases in our study had patchy arachnoiditis (radiculomyelitis), diagnosed on raised CSF proteins and lymphocytes, and myelographic findings and included partial block and irregular subarachnoid space. TB arachnoiditis remains one of the important causes of paraplegia in Indian Sub-continent and the diagnosis can be made by CSF findings, myelography and CT scan. $^{24}$ Treatment of spinal tuberculosis depends on severity and extent of neural involvement and vertebral damage. In this study, 22(50\%) out of 44 cases were subjected to laminectomy and recovery was 20/22 (90.91\%). However, overall recovery was 30/44 (68.18\%). This reflects late reporting/delay in the diagnosis, resulting into $50 \%$ cases subjected for surgical treatment. If reported early, conservative chemotherapy can give good results. Anti-tuberculous drugs can reach the tuberculous caseous material and cavities in spine. ${ }^{25}$ However, if severe bone involvement accompanied by cord or root compression is present, surgical treatment is the only remedy. ${ }^{26-28}$ Judicial combination of conservative therapy and surgical decompression has also been advocated by Tulsi, et $\mathrm{al}^{18}$. In their series of 100 cases, $50 \%$ required surgical treatment. However, in the series of 20 cases presented by Acikgoz, et $\mathrm{al}^{29}$, $13(65 \%)$ cases improved well, whereas $7(35 \%)$ cases did not show appreciable recovery. In our study, 30 (68.18\%) cases showed remarkable recovery, whereas 14 (31.82\%) showed poor response.

\section{CONCLUSION}

In our set up, TB spine is more common in males than females and mostly presents with history of fever and backache resulting into paraplegia and paraparesis. Thoracic region is more common area of involvement, followed by lumbar and cervical regions respectively. Most common pattern of TB spine is Pott's disease followed by paravertebral abscess (with or without vertebral bony destruction), spinal stenosis, 
arachnoiditis and spinal cord ischaemia. Delay in diagnosis results in poor recovery so stress should be given to detect the TB spine earlier for remarkable recovery and avoidance of surgical intervention.

\section{REFERENCES}

1. Sigerist HE. Disease in time and space. Hist Med. 1951; 53-4.

2. Rand C, Smith MA. Anterior spinal tuberculosis: paraplegia following laminectomy. Ann $\mathrm{R}$ Coll Surg Engl. 1989;71(2): 105-9.

3. Govender S, Kumar KP. Cortical allografts in spinal tuberculosis. Int Orthop. 2003; 27(4):244-8.

4. Alessi $G$, Lemmerling $M$, Nathoo $N$. Combined spinal subdural tuberculous empyema and intramedullary tuberculoma in HIV-positive patient. Eur Radiol. 2003;13(8):1899-901.

5. O'Hickey SP, Pithie A, Skinner C. Unusual spinal tuberculosis after adequate chemotherapy for lymph node tuberculosis in an immuno-competent man. Thorax. 1992; 47(11):986-7.

6. Weinberg J, Silber JS. Infections of the spine: what the Orthopaedist needs to know? Am J Orthop. 2004;33(1):13-7.

7. Griffiths DL, Seddon HL, Roaf R. Pott's paraplegia. Oxford University Press, London. 1956.

8. Desforges JF. Current concepts - spinal cords compression from epidural metastases. New Eng J Med. 1992; 327(9): 614-9.

9. Thompson AJ, McDonald I. Multiple sclerosis. Med International. 1992; 5(17): 4109-13.

10. Boxer DI, Pratt C, Hine AL, et al. Radiological features during and following treatment of spinal tuberculosis. Br J Radiol. 1992; 65(774): 476-9.

11. Jalleh RD, Kuppusamy I, Mahayiddin AA, et al. Spinal tuberculosis: a five years review of cases at the National Tuberculosis Centre. Med J Malaya. 1991; 46(3): 269-73.

12. Bernaerts A, Vanhoenacker FM, Parizel PM, et al. Tuberculosis of the central nervous system: overview of neuroradiological findings. Eur Radiol. 2003; 13(8):1876-90.
13. Dei-Anang K, Hase U, Schurmann K. Epidural spinal abscesses. Neurosurg Rev. 1990;13(4): 285-8.

14. Moon MS, Moon JL, Moon YW, et al. Pott's paraplegia in patients with severely deformed dorsal or dorsolumbar spines: treatment and prognosis. Spinal Cord. 2003; 41(3): 164-71.

15. Shanley DJ. Tuberculosis of the spine: imaging features. AJR Am J Roentgenol 1995;164 (3): 659-64.

16. Mann JS, Cole RB. Tuberculosis spondylitis in the elderly: a potential diagnostic pitfall. $\mathrm{Br}$ Med $\mathrm{J}$. 1987; 294:1149-50.

17. Loembe PM, Assengone Zeh $\mathrm{Y}$, Guerch M, et al. Vertebral tuberculosis in Gabon-Anatomo-Clinical aspects. Diagnostic and Therapeutic problems, 107 cases from 1976 to 1986 . Neurochiruric 1988; 34(6): 420-7.

18. Tulsi SM. Treatment of neurological complications in tuberculosis of the spine. J Bone Joint Surg. 1969; 51-A:680-92.

19. Hoffman EB, Crosier $\mathrm{JH}$, Cremin. Imaging in children with spinal tuberculosis. J Bone Joint Surg. 1993; 57-B(2): 233-9.

20. Vidyasagar $C$, Murthy HK. Spinal tuberculosis with neurological deficits. Natl Med J India. 1996; 9 (1):25-7.

21. Al-Arabi KM, al-Sebai MW, al-Chakaki M. Evaluation of radiological investigations in spinal tuberculosis. Int Orthop. 1992;16(2):165-7.

22. Hodgson AR, Skinshes OK, Leong JCY. The pathogenesis of Pott's paraplegia. J Bone Joint Surg. 1967; 49-A:1147.

23. Sankarah Kutty M, Chowdhary UM, Coror JR, et al. The role of CT scan in the management of spinal tuberculosis. Int Orthop. 1991;15(4):319-21.

24. Fukuta S, Miyamoto K, Msuda T, et al. Two-stage (posterior and anterior) surgical treatment using posterior spinal instrumentation for pyogenic and tuberculotic spondylitis. Spine. 2003;28(15): E 302-8.

25. Muckley T, Schutz T, Kirschner M, et al. Psoas abscess: the spine as a primary source of 
infection. Spine. 2003;28(6):E106-13.

26. Sinha S, Singh AK, Gupta V, et al. Surgical management and outcome of tuberculous atlantoaxial dislocation: a 15-year experience. Neurosurgery. 2003; 52 (2):331-8; discussion 338-9.

27. Behari S, Nayak SR, Bhargaa $V$, et al. Craniocervical tubrculosis: protocol of surgical management. Neurosurgery. 2003; 52(1): 72-81.

28. Raut AA, Narlawar RS, Nagar A, et al. An unusual case of $\mathrm{CV}$ junction tuberculosis presenting with quadriplegia. Spine. 2003;28(15): E309.

29. Acikgoz B, Ozcan OE, Belen D, et al. Surgery for progressive Pott's paraplegia (tuberculosis paraplegia). Paraplegia. 1991;29(8):537-41.

\section{莎}

AUTHOR AFFILIATION:

Dr. Bikha Ram Devrajani (Corresponding Author)

Assistant Professor

Department of Medicine

Liaquat University of Medical and Health Sciences

(LUMHS), Jamshoro, Sindh-Pakistan.

Dr. Rafi Ahmed Ghori

Associate Professor of Medicine

LUMHS Jamshoro.

Dr. Nizamuddin Memon

Associate Professor of Radiology

LUMHS Jamshoro.

Dr. Muhammad Ali Memon

Assistant Professor of Biochemistry

LUMHS Jamshoro. 